\title{
The semiotics of animal freedom: A zoologist's attempt to perceive the semiotic aim of $\mathrm{H}$. Hediger
}

\author{
Aleksei Turovski \\ Estonian Marine Institute and Tallinn Zoo, \\ Paldiski mnt. 145, 13522 Tallinn, Estonia \\ e-mail: p.turovski@tallinnlv.ee
}

\begin{abstract}
The works, views and ideas of Heini Hediger (1908-1992), one of the most distinguished and influential zoologist of the 20th century, had and still have an enormous impact on contemporary understanding of animal behaviour. His views on territorial, social, etc. aspects of animal behaviour are based on semiotic concepts derived from Umwelt-theory (J. v. Uexküll) and combined with ideas from modern ethology. Hediger's special attention was devoted to the area of animal-man communications; he treated these problematic phenomena as a system of semiosis-processes, in a mainly holistic way. Hediger's approach inspires the author to propose a notion "the need for impression" to be used in zoosemiotic analyses.
\end{abstract}

My childhood dream, my lifelong wish, would have been fulfilled if it had really been possible to converse with animals.

H. Hediger (1985: 177)

There's a disadvantage in a stick pointing straight (because) the other end of the stick always points the opposite way. It depends whether you get hold of the stick by the right end.

G. K. Chesterton (1984: 221)

There have never been any difficulties in pointing out the signs of captivity: the bars and gratings, the fetters and shackles, the nets and traps: signs of obstacles, hindrance and limitations of any kind will 
certainly do. But it is not at all easy to find a universally acceptable and generally comprehensible symbol even of human freedom, so what could serve us as a sign of animal freedom? The image of an animal moving freely is a sign of escape rather than that of a free life par excellence. The general notion of a free animal has always been something of vague perception of a completely undetained creature, imperceptible though certainly dwelling somewhere in the wild.

It is hard to believe in our time, but it seems that Heini Hediger (1908-1992) really was the first zoologist who realized that there is no such thing as an animal that is free in anthropomorphic sense: "the free animal does not live in freedom: neither in space nor as regards its behaviour towards other animals (Hediger 1964). Animals in the wild are "bound by space and time, by sex and social status" (Hediger 1985: 158). If we consider now that Hediger also elaborated on the distinction between nest and home, the former being a repository for eggs and raising the young" ... and the latter "a place of refuge, which is the function of the home" (Hediger 1985: 178), it becomes quite clear, for a zoologist at least, how Hediger approached the phenomena of animal life. He did it from within, treating the living world as the Umwelt in Jakob von Uexküll's sense.

To Uexküll Hediger dedicated his study on tameness (Hediger 1935). He was a friend and admirer of Jakob von Uexküll and Thomas A. Sebeok, but was he a semiotician? As far as I know, he was a zoobiologist and field zoologist in the first place, deeply involved in zoopsychological and behavioural studies, friend and adherent of K. Lorenz and N. Tinbergen, though not an ethologist proper (Hediger 1985: 178-179). Having enormous experience in ecology of animal behaviour both in the field and in captivity, Hediger doubted the somewhat rigid interpretations of the instinct, the ritualistic behaviour in the first place, adopted by ethology as a science of species-specific behaviour of animals. Indeed, the vast diversity of deviations from the main schemes of instincts within one and the same species, the flexibility and continuity of the adaptive behaviour of animals give us reason to belive, that the individual organism itself is the most active interpreter of the innate mechanisms of behaviour and that the main matrix on which these interpretations evolve during the ontogenesis is the semiosphere. Hediger distrusted "the accepted evolution theory" not accepting the claim that the "two major constructors of speciation are mutation and selection" (Hediger 1985: 179). And Hediger certainly was not a behaviourist in classical sense. It is my conviction that, in 
all his studies, especially "The Clever Hans phenomenon from an animal psychologist's point of view" (Hediger 1981), Hediger operated with conceptual notion-instruments 'signum-structure' in the cases where the behaviourism would apply the famous 'stimulusreaction' scheme instead. In all his studies and encounters with animals in the field and in the zoo Hediger's attention was driven to the biological meaning of the signal - an impulse of information passing between animal and other components of the Umwelt, including all human factors as well. This reminds me of what my father Markus Turovski, a philosopher, once said to me about his attitude to living things: "If I were told that an octopus can talk in, say, English or Russian, I would consider it simply as a fact of its personal biography. What it is talking about is the only thing that matters to me".

Thomas A. Sebeok describes Hediger as a "visionary innovator who reached from the inside outwards entirely comfortable within Jakob's [von Uexküll — A. T.] Umwelt paradigm, but implicitly with (zoo) semiotics too, which he came increasingly and quite explicitly to embrace" (Sebeok 2001). Sebeok highly values Hediger's works on territorial and social behaviour, especially his concepts of 'individual distance' and 'home range' together with distinguishable 'territorial idiolects and dialects' as characteristics for the communicative patterns of the species sharing a home range, and also Hedigers views on hierarchy and dominance in animal social status, on parental care and other forms of communicative stimulation/inhibition activities. In these concepts as well as in all his logically extremely coherent works, Hediger is estimated by Sebeok as a true zoosemiotician whose works offer materials and ideas of great importance for semiotics of all scientific trends, - anthropological, perhaps, in the first place (Sebeok 1972: 172-173; 1989: 5, 55; 1990: 107, 124).

Hediger, though he perhaps probably did not call himself a semiotician, obviously worked like one. And following the aim of his works, we could describe the free animal as a representative of a particular species, active in its specific semiosphere as part of the Umwelt. The contacts (and conflicts) between an animal and human culture, and furthermore between its species and civilization could be then understood as interactions between animal and human semiospheres, so the main aspect of these interactivities is the dynamics of attention on both sides.

In "Communication between man and animal" (Hediger 1974), "Man as a social partner of animals and vice-versa" (Hediger 1965), 
"Wild Animals in Captivity" and many other studies Hediger emphasizes the absolute necessity of understanding the actual animal-man encounter situations by their signs as examined from animals' point of view in the first place, in order to find optimal means of control. "People never answer what you say. ... They answer what they think you mean" (Chesterton 1984: 76). Actually animals act in the same way and it is, essentially, up to the inquisitive interrogator - the man, to arrange "the questionaire" by meanings, that is, to formulate it semiotically in elaborated sets of signs, fitted in to the space-time structure of the semiosphere of particular animal species. In the course of a life time, that is in embryonic, postnatal, juvenile, subadult, adult/imagial-sexually mature and postmature periods an animal passes through a succession of very different behavioural stages of orientation to other animals (and man) as objects of its attention. One of the important attitudes in this process besides the motivational attitudes to resources, foes, sexual partners, social ranks, broods etc., is the fulfilment of the need to be impressed by changing signals - impulses of information from the environment, otherwise indifferent in the aspects of major biological needs/functions. The matrix structure of the semiosphere of the animal obviously transforms these signals into signs in accordance with the prevailing motivations; so the forms of the Umwelt become semiotically involved in unique personal experience of the animal in dependence on its ontogenetic age-period. Such a 'need for impression' is presumably coupled with the need to impress and thus to provoke feedback signals which also contribute to the process of semiosis. Man has been making use of the need for impression, calling it "natural curiosity" of animal, in taming and domestication.

Apparently there is no such thing as a "free population", to say nothing of "a free species". But a free animal could, perhaps, be usefully imagined as a healthy member of a healthy population of a certain species dwelling in such part of the land- or seascape which is safe from foes but promising in resources as far as this animal can recognize by its semiotic means within the range and limitations of its sensorics. Or, to make long story short, free is an animal for which the fulfilment of the need for impression is granted by the functional structure of the semiosphere.

For a free animal, the best way to avoid encounters with all and any possible enemies is assumably to make itself imperceptible, to dissolve semiotically into its habitation, become undetectable. But this 


\section{Aleksei Turovski}

can be effective no longer than the event of disclosure happens. From this moment on the next necessary and diligent course of action is either to flee or, if the escape is impossible or of dubious effect - , to kill or scare the enemy off, or to gain time by stunning it, making it to hesitate even for a moment.

Presumably, the best way to do this is to produce such a complete set of the signs of danger, as to force every particular enemy to choose by itself the most horrifying pattern in accordance with its specific properties and personal experience. That can be done to any animal species because all forms of animal life are united semiotically by the need for impression. Quite convincing evidence of the importance of this need in case of humans could be easily found by approximate estimation of the numbers of horror films addicts. In the well known scheme of the mimicry the most active, essential role belongs to the "dupe". The "dupe" is the actual decider on the course of events and final results in all situations where camouflage, mimicry and other suchlike phenomena are involved. So, it is the "dupe" to whom the set of repelling patterns of form and behaviour is offered to make its own choice what particular sign to be scared of. And it is ecologically essential that the life of the dupe must be preserved (e.g., Martens mimicry clearly shows in case of deadly coral snakes that they are mimics, but not models), for a dead dupe can neither learn, nor pass the knowledge. Semiotically man holds the unique position in the Umwelt, viewed in the aspect of mimicry in "hide, seek, scare and catch" games, because man could rationally take on any or all of these roles at the same time, avoiding being duped. That gives humans the most advantageous position as hunters, tamers, domesticators, and a most perilous exterminators as well. Unless I am very much mistaken, such was the main concern of Heini Hediger as a zoologist, zoo director and a man to whom the communications with animals and zoological studies were at least equally important. This dualistic attitude could probably be marked as romantic, but it certainly is semiotic.

If I may be allowed a lyrical reminiscence, Hediger's inclination to approach life problematics "from within" reminds me of Geheimer Archivarius Lindhorst, actually a Salamander (Fiery Spirit of Nature), the most powerful character in Hoffmann's "Der goldne Topf" (Hoffmann 1814), whose principle was to act always "from within out" in order to restore the harmony between man and Nature.

All my personal experience obtained in 28 years with animals in Tallinn Zoo indicates clearly that the main and very first concern of an 
animal that founds itself outside its enclosure is to ensure the safest and straightest way back home. This home as it is pointed out above is in Hediger's sense a place for refuge. But to recognize the home from outside could be extremely difficult for an animal (and also for human as it happens in various situations), accustomed to experience the world strictly from within. So the animal is always most grateful (or at least we can say: relieved) for any assistance from the part of humans (or other animals, e.g. dogs), which are considered by the animal as its conspecifics, if the animal is tamed or properly acquainted with man. Generally speaking, humans could find themselves in very similar but reversed situation in the nearest future. Until recent years the concept of civilization for the majority of at least Western Europeans has obviously been based on the conviction that the landscape is something extremely stable and unchanging "by itself". Now, with the global warming and other suchlike troubles it seems to be possible that people would find themselves on the "outside" from their home and with anxious expectations that just animals will "show the way back inside". I think that such would have been $\mathrm{H}$. Hediger's feelings nowadays.

As for Hediger's doubts about the synthetic theory of evolution, those I think were based mainly on such observable events as the preference given by females to childlike or otherwise deviated males instead of some very masculine ones, the general infantilization and sexual acceleration in zoo animals (but not only them), on striking importance of imprinting combined with games and teaching in raising the young in predatory mammals and birds (but also some fish and even insects, e.g, Passilidae, Coleoptera), and on the vast variability in communication patterns in animal behaviour. But, as all the scientific legacy of Hediger, this topic needs further studies. Reproductive isolation may occur within a population due to behavioural particularities of single organisms. It is well known that in some cases females prefer the males clearly deviated from the median pattern of behaviour, e.g. wasps Mormoniella vitripennis (White, Grant 1977), Drosophila sp. sp. in the phenomenon of asymmetric evolution on Hawaii islands (Lambert 1984), though, as a rule, female mate choice favours symmetrical males in such different species as barn swallows ( $\mathrm{Hi}$ rundo rustica), earwings (Forficula auricularia), humans (Homo sapiens) and many other (Polack 1997). From my part, the study of the possibilities to apply the Baldwin principle in the analyses of zoosemiotic views of Hediger seems to be very promising. In this field especially interesting would be to try the application of K. Kull's ideas 
on Osborn-Baldwin effect (Kull 2000). According to his interpretation of this effect, "the activity of an organism as a subject may play a role as an evolutionary factor" (Kull 2000: 53).

One must not expect to have a powerful and beautiful waterfall without the river. Such expectations can never arise where the Umwelt theory is semiotically correctly applied as it was always done by Dr. Heini Hediger in all his studies.

\section{References}

Chesterton, Gilbert Keith 1984. The Penguin Complete Farther Brown. London: Penguin Books.

Hediger, Heini 1935. Zähmung und Dressur wilder Tiere. Cibz. Zc. Basel 3: 27.

- 1964. Wild Animals in Captivity: An Outline of the Biology of Zoological Gardens. New York: Dover Publ.

- 1965. Man as a social partner of animals and vice-versa. Symposia of the Zoological Society of London 14: 291-300.

- 1974. Communication, between man and animal. Image Roche (Basel) 62: 27-40.

- 1981. The Clever Hans phenomenon from an animal psychologist's point of view. Annals of the New York Academy of Sciences 364: 1-17.

— 1985. A lifelong attempt to understand animals. In: Dewsbury, D. A. (ed.), Leaders in the Study of Animal Behavior: Autobiographical Perspectives. Lewisburg: Bucknell University Press, 144-181.

Hoffmann, Ernst Theodor Amadeus 1814. Fantasiestücke in Callots Manier, Bd. 3. Berlin: Kunz Verl.

Kull, Kalevi 2000. Organisms can be proud to have been their own designers. Cybernetics and Human Knowing 7(1): 45-55.

Lambert, David M. 1984. Specific-mate recognition systems, phylogenies and asymmetrical evolution. Journal of Theoretical Biology 109(1): 147-156.

Polak, M. 1997. Parasites, fluctuating asymmetry, and sexual selection. In: Beckage, Nancy E. (ed.), Parasites and Pathogens: Effects on Host Hormones and Behavior. New York: Chapman \& Hall, 246-276.

Sebeok, Thomas A. 1972. Perspectives in Zoosemiotics. The Hague: Mouton.

- 1989. The Sign and its Masters. London: University Press of America.

- 1990. Essays in Zoosemiotics. Toronto: University of Toronto.

- 2001. Biosemiotics: Its roots, proliferation, and prospects. Semiotica (special issue about Uexküll, forthcoming).

White, H. C. and Grant, B. 1977. Olfactory cues as a factor in frequencydependant mate selection in Mormoniella vitripennis. Evolution 31(4): 829-835. 


\section{Семиотика животной свободы: попытка зоолога понять семиотическую цель X. Хедигера}

Работы, взгляды и идеи Хейни Хедигера (1908-1992), одного из наиболее известных и влиятельных зоологов 20 в., имели и до сих пор имеют огромное значение для современного понимания поведения животных. Его взгляды на территориальные, социальные и другие аспекты поведения животных основаны на семиотических концептах, заимствованных из Umwelt-теории (Я. Юкскюлль) и соединенных с идеями современной этологин. Особое внимание Хедигер уделял коммуникации животного и человека: он рассматривал это проблематичное явление прежде всего холистически как систему процессов семиозиса. Хедигеровский подход побудил автора исследования предложить для использования в зоосемиотических исследованиях понятие “потребность впечатления".

\section{Loomse vabaduse semiootika: zooloogi katse mõista H. Hedigeri semiootilist eesmärki}

Heini Hedigeri (1908-1992), ühe 20. sajandi tuntuima ja mõjukama zooloogi tööd, vaated ja ideed omasid ja omavad siiamaani suurt tähtsust loomade käitumise mõistmisel. Tema vaated loomade käitumise territoriaalsetele, sotsiaalsetele ja muudele aspektidele toetuvad semiootilistele kontseptidele, mis on tuletatud Jakob von Uexkülli omailma teooriast ning on täiendatud kaasaegse etoloogia ideedega. Erilist tähelepanu pööras Hediger inimese ja looma vahelisele kommunikatsioonile, vaadeldes seda probleemset nähtust eelkõige holistlikust vaatepunktist kui semioosise protsesside süsteemi. Hedigeri lähenemine inspireeris käesoleva uurimuse autorit pakkuma välja zoosemiootiliste analüüside tarbeks mõiste "muljete tarve". 